\title{
IN HOUSE OR IN COURT? LEGAL CHALLENGES TO UNIVERSITY DECISIONS
}

\author{
Ms Patty Kamvounias \\ Lecturer in Business Law \\ University of Sydney \\ Australia \\ E-mail: p.kamvounias@econ.usyd.edu.au \\ Dr Sally Varnham \\ Senior Lecturer in Law \\ Massey University Wellington Campus \\ New Zealand \\ Email: s.e.varnham@massey.ac.nz
}

\begin{abstract}
Every day, universities are making decisions that affect their students. When a decision adversely affects a particular student, what means of redress does that student have? The circumstances in which a student may have a legal claim against their university is generally unclear. Courts have traditionally tended to draw a distinction between non-disciplinary and disciplinary decisions made by universities. Non-disciplinary decisions are those decisions that involve academic judgment, for example, the grade to be given to a student's work. The courts have shown a reluctance to intervene in this area. On the other hand, where the decision is purely disciplinary, for example, in relation to a student's behaviour towards others or towards university property, the courts have made it clear that there is essentially no difference between this and disciplinary matters within any other public institution or organisation. However, disciplinary decisions that are connected with allegations of academic misconduct, for example, cheating and/or plagiarism, have been more problematic for the courts. Historically, the debate surrounding the ability of the student to legally challenge university decisions focussed upon whether the decision was justiciable in public law. In recent times, disciplinary decisions have also raised new questions about the extent to which a court will entertain a private law action by a student against a university. The legal issues raised by university decisions affecting students have only recently come before the courts and have certainly not yet been clearly resolved in all jurisdictions. Indeed, in some cases, many more questions have been raised than answered by the judges. This session will provide a clearer understanding of the framework for legal challenges to university decisions against a background of the attitudes adopted by courts in Australia, New Zealand, the United Kingdom and the United States.
\end{abstract}

\section{Introduction}

University teachers, boards, committees and other bodies constituted under university regulations make a variety of decisions which affect their students and which may impact 
significantly upon those students' expectations. Examples include decisions about enrolment, subject choice, assessment, credit for prior learning, research supervision and so on. In making such decisions universities are bound by their processes and procedures and by the rules of natural justice. Inevitably, some decisions will be challenged by the students concerned.

The types of university decisions challenged in the courts by students fit largely into three categories. First, there are decisions which involve academic judgement, for example, the grade to be given to a particular piece of work, whether to pass or fail a student on academic grounds, or whether to exclude a student from a course for insufficient progress. There are then two types of disciplinary decisions. One relates to conduct unconnected with academic achievement, for example, a student's behaviour towards other students or university property. It is not intended to deal here with this type of decision except to note that the courts have made it clear that students in such cases have a right to a fair hearing as there is essentially no difference between disciplinary matters within a university and disciplinary matters within any other public institution or organization. ${ }^{1}$ Then there is the second type of disciplinary decision which follows a finding of academic misconduct such as cheating in examinations, plagiarism in written work, or some other form of misconduct which has the effect of bringing the student's research into question.

In deciding whether to intervene, courts initially focussed on the type of university decision being challenged. ${ }^{2}$ A review of the early cases indicates the courts were careful to distinguish between 'purely academic' decisions and academic disciplinary decisions. More recent

$1 \quad$ For example, in the United Kingdom Glynn $v$ Keele University [1971] 1 WLR 487, in the United States, Dixon v Alabama State Board of Education 294 F.Ed 150 (5 ${ }^{\text {th }}$ Cir. 1961) and in Australia Bray $v$ The University of Melbourne [2001] VSC 391.

$2 \quad$ See Varham, S. (2002) Copping Out or Copying? Do Cheats Prosper? An Exploration of the Legal Issues Relating to Students Challenging Academic Decisions. Australia and New Zealand Journal of Law and Education, 7(1):21-37. 
authority suggests the courts now lean more towards a concern with the circumstances in which it is necessary and desirable for the court to intervene. Perhaps the better view is that there is a spectrum upon which each case should be considered on its individual facts with courts being guided predominantly by considerations of fairness. The court's primary examination is whether on the facts there was sufficient indication of a failure on the part of the university to adhere to their published processes or that there was a lack of fairness or justice. The first consideration here relates to decisions of academic judgment. We will then move on to the judicial attitudes in relation to decisions involving academic misconduct.

\section{'Of academic independence and other concerns'}

Those 'purely academic' decisions at one end of the spectrum are those 'pertaining to the intimate life of every independent academic institution that, sensibly, courts decline to review'. ${ }^{4}$ Examples include: the marking of exam papers, the academic merit of a thesis, the viability of a research project, the contents of courses, timetables and styles of teaching. Universally, courts have shown a reluctance to revisit such decisions. However, the cases show that there may be a difficulty in deciding when that reluctance may properly be overcome and when the decision is justifiably subject to the court's scrutiny. Generally, the prevailing view has been that academic judgement should only attract judicial interference when it can be shown that there was a lack of adherence to due process or when the person or body responsible did not actually exercise professional judgement. Traditionally courts have been prepared to intervene only when the actions were 'capricious' or arbitrary. The US Supreme Court decisions in The Board of Curators of the University of Missouri $v$ Horowitz

$3 \quad$ Griffith University $v$ Tang [2005] 213 ALR 724 at 767 per Kirby J.

n 2 at 767 per Kirby J. 
and The Regents of the University of Michigan $v$ Ewing illustrate this attitude. ${ }^{5}$ Consistent with this view also is the more recent decision of the New York Court of Appeals in Susan M $v_{\text {New York Law School. }}{ }^{6}$

In Ivins $v$ Griffith University, ${ }^{7}$ a first year nursing student's application for judicial review of teaching decisions, including the use of group work in assessment, which allegedly resulted in her failure of two subjects, was dismissed because no basis for judicial intervention had been established. Philippides J, citing $R v$ Aston University Senate; ex parte Roffey, ${ }^{8}$ found no improper exercise of power as "the rules of natural justice were adequately met by the procedure set out in the University's policy and did not require that, in addition to the written submissions of the applicant, the applicant should have been afforded an opportunity to be present and to have been heard orally." ${ }^{\text {9 }}$ In the view of Williams JA in the Court of Appeal: ${ }^{10}$

Clearly when it is purely a question of academic assessment or academic judgement the student has no right to be present on the marking of examination papers. It may well be different if the evaluation of the student's progress or the question of exclusion of a student from the university involves questions other than mere academic judgment.

Douglas $\mathrm{J}$ agreed that the appeal should be dismissed and added the following remark ${ }^{11}$ :

I want to say that this application is one which relies upon a failure by the appellant to accept that she did in fact fail two subjects in her course, one of which was a prerequisite to her continuing in that course. That, without more, is not sufficient to mount a successful application for relief.

435 U.S. 78, 98 S.Ct.948, 55 Ed. 2d 124 (1978); and 474 U.S. 214, 106 S.Ct 507, 88 L.Ed.2d (1985) respectively. For further discussion of the US view see Ford, D.L. \& Strope, J.L.Jr (1996) 'Judicial Responses to Adverse Academic Decisions Affection Postsecondary Students since "Horowitz" and “Ewing”', 110 Ed.Law Rep. 517, at p 531, and Schweitzer, T.A. “'Academic Challenge” cases: should judicial review extend to academic evaluations of students?' The American University Law Review, 41:267.

$6 \quad 76$ N.Y. 2d 241, 556 N.E. 2d 1104, 557 N.Y.S. 2d 297 (1990)

[2001] QSC 086.

[1969] 2 QB 538 at 554

$\mathrm{n} 6$ at [42]

[2001] QCA 393

n 9 
Courts in the United Kingdom and New Zealand particularly, when confronted with early student challenges, were concerned essentially with their jurisdiction in relation to that of the University Visitor. $^{12}$ This was the case in Norrie $v$ Senate of the University of Auckland ${ }^{13}$. Norrie had applied for judicial review of a decision of the Faculty of Medicine. His application for enrolment for his final year as a medical student had been declined. While deciding that, in principle, a university decision may be subject to the scrutiny of the courts, Woodhouse P, speaking for the majority of the Court of Appeal said: ${ }^{14}$

I have great difficulty in understanding why it should be thought that wherever the visitor is able to act the actual jurisdiction of the Courts has been ousted.

While he was careful to exclude matters of purely academic judgement from the court's jurisdiction, he clearly stated that in his view there was a compelling argument for the courts' scrutiny of some university decisions in light of the fact that they are bodies set up to promote a public purpose using public funds. ${ }^{15}$

12 In the United Kingdom, the role of the Visitor in student complaints and appeals has recently been removed by legislation (See Reddy, M. [2004] The Office of the Independent Adjudicator for Higher Education: Preparing for the Statutory Scheme, Education Law Journal; and Hoye, W.P. \& Palfeyman, D. (2004) Plato vs Socrates: the devolving relationship between higher education institutions and their students Education and the Law, 16 (2-3); 97-113 at 95. New Zealand universities also no longer have a Visitor and the statutory responsibility for investigation of student complaints now rests with the Ombudsman. The situation in Australia is more complicated. In some states (Queensland, Victoria and South Australia) there is no provision in the university statutes for there to be a Visitor while in others (New South Wales and Tasmania), the Governor is the Visitor of the University but has ceremonial functions only. In Western Australia, the Governor is the Visitor but has authority to do all things that pertain to the office of the Visitor. And in all states, the Ombudsmen have some jurisdiction regarding university decisions. See also Astor, H. (2005) Improving Dispute Resolution in Australian Universities: Options for the Future. Journal of Higher Education Policy and Management, 27(1): 4965; and Stuhmcke, A. (2001). Grievance Handling in Australian Universities: The case of the University Ombudsman and the Dean of Students. Journal of Higher Education Policy and Management, 23(2): 181-189.

[1984] 1 NZLR 129

n 12 at 134 .

n 12 at 135 . 
Similarly, the House of Lords, in $R v$ Lord President of the Privy Council, ex parte Page, ${ }^{16}$ held that a visitor's decision was reviewable by the courts but only where it was demonstrated to be ultra vires or in breach of rules of natural justice.

Visitor aside, the essential inquiry is whether the courts may intervene in academic judgment decisions made pursuant to internal assessment and appeal processes. Universally the answer has been 'yes' but only in cases of unfairness. In New Zealand this is illustrated by a recent decision of the High Court to decline the application of Tania Lamb for judicial review of decisions of the Palmerston North College of Education (later Massey University). ${ }^{17}$ Lamb failed a number of subjects and the College refused to allow her to complete her teaching practice. She alleged bias, breach of her legitimate expectation that her work would be assessed fairly and consistently with other students, and breach of the right to natural justice under Section 27 of the New Zealand Bill of Rights Act $1990 .{ }^{18}$ However, the court was not satisfied on the evidence that Lamb had demonstrated any unfairness or breach of legitimate expectation by the College or any persons involved in the decisions. Accordingly, it held against the student on all aspects of the application for judicial review. ${ }^{19}$

Decisions in the United Kingdom are consistent with this view. The courts there have been prepared to impugn the exercise of academic judgement only where there was clearly a failure to comply with procedures ensuring natural justice or where there were grounds for doubting

\footnotetext{
$16 \quad$ [1992] 3 WLR 1112.

17 Lamb v Massey University Unreported Judgment of Wild J, High Court of New Zealand, Palmerston North Registry, $19^{\text {th }}$ October 2004, CIV 2003454336 \& 337.

18 This Act applies to the actions of public authorities and as such is the equivalent of Art 6(1) of the European Convention of Human Rights, given effect to in domestic UK law by the Human Rights Act 1998 (UK). For a comprehensive discussion of the role of the Human Rights Act 1998(UK), particularly Art 6(1) see Davies, M. (2004) Challenges to 'academic immunity' - the beginning of a new era? Education and the Law, 16 (2-3): 75-96, at 78-86; Kaye, T. 1999) Academic Judgement, the University Visitor and the Human Rights Act 1998 Education and the Law, 11(3): 165-186 and Arthur, M. (2001) The Human Rights Act and higher education, Education and the Law,13(4): 285-301. The student's allegation of breach of contract by the college also failed, see below.
} 
the basis of the judgement. ${ }^{20} R v$ Cambridge University ex parte Persaud, Persaud $v$ Cambridge University ${ }^{21}$ is one such case.

In 1993 Jennifer Persaud was admitted as a PhD student within the Institute of Astronomy at the University of Cambridge. Her research progression was intermittent and she was involved in a series of disagreements with successive supervisors. In 1997 the Director of the Institute formed the opinion that she should withdraw as her work was unlikely to reach the standard of a PhD thesis and he recommended this action to the Registrar of Graduate Students. Following submissions from Persaud it was decided that she could continue her PhD under several conditions which were conveyed to her and she agreed to them. Things did not improve and in July 1998, after receiving an opinion from a 'senior academic in the field', the Board of Graduate Studies decided to remove her name from the register of Graduate Students. Although she had started work on a new research project with a new supervisor, she attempted to appeal the decision, requesting confirmation of what she referred to as the 'oral assurances' that she would be reinstated at the point she was ready to submit her thesis. The Institute declined on the basis that she had now embarked on a new, and entirely different, research project. Persaud requested copies of the reports which had led to the decision to discontinue her candidature but the university declined to make the reports available.

Persaud applied for judicial review of the decisions. Essentially her application was based on lack of fairness. At first instance, Maurice Kay J dismissed the application. In his view there was nothing in the actions of the university which demonstrated a breach of a duty to act

\footnotetext{
$20 \quad R v$ Higher Education Funding Council, ex parte Institute of Dental Surgery [1994] 1 All ER 651; $R v$ Board of Governors of Sheffield Hallam University and others, ex parte Rowlett [1995] ELR 267; Thirunayagam v London Guildhall University, Unreported Judgment, Hirst LJ, Court of Appeal, 14 $21 \quad$ March 1997. [2001] EWCA Civ 534.
} 
fairly. However, the Supreme Court of Judicature Court of Appeal (Civil Division) decided that the university had acted unfairly and allowed the appeal in part. ${ }^{22}$ In the judges' view it was a question of fact whether the Board was in breach of its duty to act fairly. The failure of the Board to consider Persaud's submissions, and to reject her account of events without first putting their doubts of its accuracy to her, was unfair. So also was the failure to make available to her the reports, particularly the report of the independent academic as it appeared to raise a new issue which was the potential value of her research. The statement of Chadwick $\mathrm{LJ}$, delivering the opinion of the court ${ }^{23}$ clearly enunciates the realistic attitude of the courts to such challenges and it is consistent with case law from the comparative jurisdictions.

This view prevails in Canada also, as is clear from the analysis of case law in the decision of Sinclair J of the Manitoba Court of Queen’s Bench in the case of Al-Bakkal v de Vries. ${ }^{24}$ The judge granted an application for judicial review to a third-year dentistry student who had had marks deducted from her with the result that her grades were insufficient to enable her to progress to her fourth year of studies. The judge was satisfied that the student was a victim of a biased and unfair process of the Students Promotion Committee. ${ }^{25}$ He was also satisfied that the Faculty Council and the Senate Appeal Committee took into account considerations which had not been raised to the student and that in any event those bodies were biased by unproven allegations of cheating on the part of the student (which the student was unaware of until the judicial review hearing). After reviewing previous decisions of the Canadian

\footnotetext{
22 The court allowed the appeal in that it quashed the Board's decisions but as the student was now engaged in substantially different research the court felt that an order of mandamus would be inappropriate and would serve no useful purpose. [2001] EWCA Civ 534, at para 41. (2003) MBQB 198, 176 Man.R. (2d) 127. The internal university body which reports to the Faculty Council on whether a student is entitled to be promoted from one year to the next.
} 
Courts, ${ }^{26}$ he set out the following propositions which in his view governed the decision for the student. He said while it is the duty of the court to attribute a large measure of autonomy to the decisions of a tribunal such as the Board of Governors of a university, the tribunal must observe rules of natural justice or 'fair play in action'. Secondly, he said there was a necessity for a high standard of justice in such cases. The stakes were high as a suspension in such circumstances would have grave consequences for a person's right to pursue their profession or employment. Justice required the tribunal to listen fairly to both sides and to ensure that the party was given a fair opportunity to correct or contradict any statements which were prejudicial to them. ${ }^{27}$ Importantly, the judge did not require that the Faculty reconsider the applicant's grade, rather he ordered declarations that the mark deduction which had rendered her a fail rather than a pass was reversed; that she had therefore passed her third year of dentistry and that she be admitted to her fourth year of studies.

The point on which all the above cases turn is not whether the academic judgement decision was fair but rather whether the process by which the decision was reached was fair.

What then of decisions involving discipline for academic misconduct?

The other end of the spectrum: academic disciplinary decisions - is the attitude different?

\footnotetext{
$26 \quad$ Houston $v$ University of Saskatchewan (1994) 117 Sask. R. 291; Mikkelsen $v$ University of Saskatchewan [2000] S.J. No. 115 (Sask. Q.B.); Kane v University of British Colombia (1980)110 D.L.R. (3d) 311 (S.C.C.).

$27 \quad \mathrm{n} 23$ at para 47.
} 
Punishment for cheating is immeasurably detrimental to the career of a student. For that reason alone it is beyond question that the courts should require a rigorous adherence to the rules of natural justice.

The need for a strict adherence to natural justice was emphasised by the decision in favour of the student by a United Kingdom court in $R v$ Manchester Metropolitan University ex parte Nolan. ${ }^{28}$ Nolan was a student at the Manchester Metropolitan University and was taking the Common Professional Examination of the Inns of Court and the Law Society. He had taken some closely written pages of notes into the end-of-year examinations. The actions that were taken against the student under two sets of disciplinary procedures and rules were held by the court to have been procedurally unfair. Mitigating circumstances in terms of Nolan's mental state were not taken into account by the CPE Board of Examiners who decided that Nolan should be deemed to have failed the entire set of examinations and that he should not be permitted to re-take them. The crucial medical evidence and testimonials, which had been before the Disciplinary Committee who had heard the matter first, had not been before the Board of Examiners, neither were the minutes of the Committee hearing. The applicant was not allowed to be present. The Court quashed the decision of the Board of Examiners on the basis that it had failed to take into account the full evidence in mitigation which had been placed before and accepted by the Disciplinary Committee at the original hearing. The judge said that it was incumbent upon the Board to take such material into account and failure to do so nullified the decision.

Natural justice also dictates that the disciplinary body conducting the hearing is impartial and that there is no real danger of bias. If a disciplinary allegation arises out of some direct contact

28 [1994] E.L.R. 380. 
with a member of the staff, for example an examiner or invigilator, then that person should not be a member of the disciplinary body. The issue of bias was raised unsuccessfully in Nolan's case. Essentially, the Court there took the view ${ }^{29}$ that what amounts to unacceptable bias in a domestic or academic body must be determined in each case according to the framework in which it operates.

The argument of bias was raised, also unsuccessfully, by another student in the United Kingdom, in $R v$ Cambridge University ex parte Beg. ${ }^{30}$ The student had submitted an independent essay for a Master of Philosophy in Finance at the University of Cambridge. One of the examiners made an allegation of plagiarism. At the hearing conducted by the court of discipline, Beg agreed that there was plagiarism in the marked essay but contended that it was not the essay submitted by him but there had been a substitution by $\mathrm{Mr} \mathrm{K}$, his supervisor. His internal appeal on the grounds of bias was unsuccessful and he applied for judicial review on the same grounds. One of his arguments was that he had been penalised because of the nature of his defence which involved an attack on the integrity of a lecturer at the university. He contended that there had been a breach of natural justice as guaranteed to him by Article 6 of the European Convention for the Protection of Human Rights and Fundamental Freedoms. ${ }^{31}$ Sullivan J of the Queen's Bench Division dismissed the application, holding that there was no evidence of bias or lack of independence or impartiality on the part of the internal body.

The cases clearly illustrate that where a court is satisfied that natural justice has been properly observed the student will be hard-pushed to persuade it to overturn the decision. This was the

\footnotetext{
$29 \quad$ Later also shown in Simjanoski \& Ors v La Trobe University \& Ors [2004] VSCA 125 30 [1999] ELR. 404.

31 See n 29 above. In New Zealand the equivalent argument would be framed as a breach of s 27(1) of the New Zealand Bill of Rights Act 1990. This was argued (unsuccessfully on the facts) by the student in Lamb v Massey University, n 16 above.
} 
situation most recently in Australia in Simjanoski \& Ors v La Trobe University \& Ors ${ }^{32}$ where three maths and engineering students challenged the university's finding that they had committed acts of academic misconduct. The allegation, made by the subject convenors, was that the students, based on their examination answers and in relation to their past performances in the subjects, must have had access to the solutions paper for the exam. This view was supported by the fact that the students had reproduced in their answers minor errors in the solutions paper. The Academic Misconduct Committee of the Faculty of Science, Technology and Engineering found that the charges were proven and each student was given a zero grade for the examination and excluded from the university for a period of time. The appeal was heard and dismissed by the Reserve Proctorial Board. The students asked the Supreme Court to review the decisions. Bamford J was not concerned with whether his court had jurisdiction to grant review. Rather, he concentrated on whether the students' claims of lack of process and unfairness had been proven on the facts. He decided that they had not. He held that the Board had conducted the hearing in observance of the procedure provided in the regulations and there was no evidence of bias and no breach of principles of natural justice. The judge found that the Board had acted fairly to all parties in the manner it dealt with the material and declined the students' application for review. Leave to appeal to the Court of Appeal was refused.

It is clear from all the above cases that thus far, in the comparative jurisdictions, judicial willingness to overturn academic decisions has been solely dependent upon whether, on the facts, the student has demonstrated unfairness or the potential for unfairness in the process. There is no suggestion in the cases that the courts consider themselves unable to consider a student's application in public law for judicial review. However, when an Australian student

32 [2004] VSC 180 (27 May 2004) in the Supreme Court of Victoria; and [2004] VSCA 125 (23 July 2004) in the Supreme Court of Victoria - Court of Appeal . 
recently applied for a statutory order of review of a university's decision, the narrow view taken by the High Court seems to fly in the face of this prevailing trend.

Vivian Tang was a PhD candidate at Griffith University in Queensland. The University’s Assessment Board made a decision that she had engaged in academic misconduct on the basis of its finding that she had presented falsified or improperly obtained data as if it were the results of laboratory work. The Board then determined that she should be excluded from the PhD program because she had 'undertaken research without regard to ethical and scientific standards'. The University’s Appeals Committee upheld that decision. Having exhausted the available in-house remedies, Tang filed an application for a statutory order of review under the Judicial Review Act 1991 (QId) ('the Review Act') of the decisions made by the Board and the Appeals Committee. ${ }^{33}$ She alleged various breaches of the rules of natural justice including failures to observe proper procedures required by the policy, improper exercises of power and lack of evidence or other material to justify the decisions. Tang's application for relief and her contentions on the merits were never tried because the University almost immediately applied to dismiss or stay the proceedings. The University did not argue that Tang was not 'a person aggrieved" ${ }^{34}$ but that the question could not arise unless it could be shown that the relevant decision was 'a decision to which this Act applies'. ${ }^{35}$ The University argued that the Review Act did not apply because the decisions were made pursuant to various university policies and so were neither of 'an administrative character' nor made 'under an enactment' as required by the judicial review legislation. ${ }^{36}$

\footnotetext{
33 The questions of whether she would be entitled to a remedy under the common law or pursuant to the powers of the Supreme Court of Queensland, or otherwise, did not arise because she had relied solely on the statutory procedures and sought only the statutory remedies provided by the Review Act.

$34 \quad$ As required by section 7 Judicial Review Act 1991 (Qld)

35 Judicial Review Act 1991 (Qld) section 20. It is this expression in this section of the Act 'which provides the battleground for this litigation’: n 2 at 736 per Gummow, Callinan and Heydon JJ. Judicial Review Act 1991 (Qld) section 4.
} 
The Supreme Court of Queensland agreed with Tang that the decision could be judicially reviewed under the Review Act ${ }^{37}$ as did the Queensland Court of Appeal. ${ }^{38}$ The University however appealed to the High Court of Australia where a 4 to 1 majority ${ }^{39}$ allowed the University’s appeal and dismissed Tang's application. ${ }^{40}$ As reported in a leading national newspaper ${ }^{41}$, the highest appellate court in Australia has "done universities and other statutory corporations a wonderful service”. It held that Tang was not entitled to review under the Review Act because the relevant decision was not made under nor did it take legal force or effect from the relevant enactment, namely Griffith University Act 1998 (QId). The majority noted that nothing in that Act dealt specifically with admission to or exclusion from a research program or academic misconduct or procedures dealing with such matters. Powers in relation to these matters flowed from a general description in that Act regarding the university's functions and general powers. ${ }^{42}$ Consequently, the power to affect Tang's rights and obligations derived not from the enactment but under the general law and from such agreement as has been made between the parties. ${ }^{43}$

Why did the High Court take such a narrow view when courts in other common law jurisdictions have recognised the student's right to judicial review of university decisions in similar circumstances? Perhaps the court's approach was to some extent fashioned by the manner in which Tang framed her application for judicial review, namely that there were no legal rights and obligations under private law affected by the University’s decisions. ${ }^{44}$ Accordingly, the court noted that: ${ }^{45}$

\footnotetext{
$37 \quad$ Tang $v$ Griffith University [2003] QSC 22

$38 \quad$ Tang $v$ Griffith University [2003] QCA 571

39 Gleeson CJ, Gummow, Callinan and Heydon JJ ( Kirby J dissenting).

$40 \quad$ Griffith University v Tang (2005) 213 ALR 724

41 Moodie, G. "Little Room for Review”, The Australian, 9 March 2005, 28.

$42 \quad$ Griffith University Act 1998 (Qld) ss 5-11.

$43 \mathrm{n} 2$ at 744 per Gummow, Callinan and Heydon JJ.

$44 \quad \mathrm{n} 2$ at 746 per Gummow, Callinan and Heydon JJ.

$45 \mathrm{n} 2$ at 746 per Gummow, Callinan and Heydon JJ.
} 
There was at best a consensual relationship, the continuation of which was dependent upon the presence of mutuality. That mutual consensus had been brought to an end, but, there had been no decision made by the university under the University Act. Nor indeed, would there have been such a decision had the respondent been allowed to continue in the PhD programme.

It was a 'catch 22' situation. Had Tang pleaded a contractual relationship with the university, an application for judicial review under the Review Act would have likely failed on the same grounds as the failed applications of university employees in Australian National University v Burns ${ }^{46}$ and Australian National University v Lewins. ${ }^{47}$ Those cases made it clear that decisions made pursuant to contracts are not reviewable under the judicial review legislation. Although a plea in contract may have been fatal to the application for judicial review, it would have given the court the opportunity to look at the nature of the student/university relationship and consider whether private law (contract) would have provided the appropriate relief in these circumstances. ${ }^{48}$

Kirby J delivered a very strong dissenting judgment in Tang. He was particularly concerned that because of the way the proceedings had developed, no court had had the opportunity to examine the substance of the student's complaint. ${ }^{49}$ In essence, her complaints were: that the Chair of the Board was not impartial as he was the person who had initially investigated the complaint against her; that she had been denied legal representation and adequate time to evaluate and respond to expert witnesses relied on by the university; that the university had breached its own policy and that the decisions were not based on relevant material and evidence. ${ }^{50}$ She may or may not have been able to establish each or any of these complaints

\footnotetext{
$46 \quad$ (1982) 43 ALR 25.

$47 \quad$ (1996) 68 FCR 87.

48 Refer Clark v University of Lincolnshire \& Humberside [2000] EWCA Civ 129 below which held that rights in private law and public law may be coexistent.

49 There is no mystery in the litigation strategy of the University. By seeking an order to dismiss the application it forestalled any examination by the courts of Tang's complaints.

49 Although Kirby J outlines Tang's complaints about the decisions, it is still unclear exactly why and how the Board came to hear the allegations of academic misconduct made against her. Who were the academics who made the initial complaint? To whom had she presented the allegedly false or
} 
but the majority had cut dead any chance of her doing so by holding that the Review Act did not apply. The matter had proceeded all the way to the High Court of Australia but her claims and any arguments on their merits had never been nor would they be tried. ${ }^{51}$ In Kirby’s view this result was 'surprising': ${ }^{52}$

\begin{abstract}
Given her enrolment in the University for the degree of Doctor of Philosophy, the nature of the complaints that the respondent wished to ventilate, the public character of the University as a statutory authority substantially supported by public funds, the devastating consequences of the University 'decision' on the immediate and long-term career and reputation of the respondent and the language and purpose of the Review Act.
\end{abstract}

Kirby noted that the majority's narrow construction of the Review Act effectively left Australian university students without the means of judicial review — a right which they would normally have in other common law countries and did have in Australia until now. His view is compatible with the attitude expressed in previous cases elsewhere. Almost universally the attitude has been that it is imperative that students have recourse to the courts where it is demonstrated that irregularities in internal procedures give rise to a high possibility of their having led to an unjust result. Unfortunately, the strict adherence to statutory interpretation by the majority in Tang may serve to reinforce an academic immunity which is no longer enjoyed by other professions. ${ }^{53}$

\title{
But what of private law - does the student have rights in contract?
}

improperly obtained data? Had she submitted her $\mathrm{PhD}$ thesis for examination? Had she presented her work in progress at a research seminar? Had she submitted her work to her PhD supervisor? Had her supervisor instructed her of the appropriate ethical and scientific standards required for laboratory work? Many questions remain unanswered even after lengthy litigation.

n 2 at 749 per Kirby J.

n 2 at 752 per Kirby J.

Most notably, the removal of advocates' immunity by the House of Lords in the case of Arthur J.S.Hall \& Co (a firm) v Simons; Barratt $v$ Ansell \& others (trading as Woolf Seddon (a firm)); Harris $v$ Scholfield Roberts \& Hill (a firm) and another [2000] 3 All ER 673, [2000] 3 WLR 543. For a comprehensive discussion see Davies, M (2004) Challenges to 'academic immunity' — the beginning of a new era? Education and the Law, 16(2-3). 
When Wade wrote in $1969^{54}$ that the legal relationship of a university with its members was much more suitably governed by the ordinary law of contract and by ordinary contractual remedies much of the academic community was dumbfounded. Now, this proposition is beyond argument. ${ }^{55}$ Acceptance of the student/institute contract highlights university regulations and documentation, such as university prospectuses, as central to the relationship. In the New Zealand case of Grant, Woolley, Staines \& Grant v Victoria University, Ellis J of the High Court put the existence of a university/student contract beyond doubt when he said: ${ }^{56}$

\begin{abstract}
I think it is beyond argument that the relationship between the student (who is a member of the university: s163) and the University is partly based on contract and partly based on the [Education] Act itself ... it is therefore on the basis of contract, tort or judicial review that a student may seek redress against the University ... The Court will not adjudicate on matters which impinge on academic freedom and independence, but they will entertain an action brought by a student based on tort or his or her contract with the University which does not so impinge.
\end{abstract}

In the UK case of Clark $v$ The University of Lincolnshire \& Humberside ${ }^{57}$ the student argued breach of contract and the court supported the view that public law and private law rights are coexistent and not exclusive of each other. ${ }^{58}$ For her final examination for a degree in humanities, Clark had chosen to do a paper and presentation on 'A Streetcar Named Desire'. She did the work on computer and failed to keep a backup file. On the last day before the due date she lost all of the paper from the hard disk and instead submitted some notes copied from a commentary on the work. The examiner gave her a mark of zero, originally on the grounds of plagiarism though the university later abandoned this initial finding. The Academic Appeals Board accepted that she had not set out to deceive and sent the paper back to the

$54 \quad$ Wade, H.W.R. (1969) Judicial Control of Universities 85 LQR 468.

55 Moran v University College Salford (No.2) [1994] ELR 187, CA; Sammy v Birkbeck College, The Times,3 November 1964.

56 Unreported Judgment of the High Court of New Zealand, Wellington Registry, Ellis J, 13 November 1997, СР312/96.

57 [2000] EWCA Civ 129.

58 see Kos, J.S. (1999) View from the Bottom of the Cliff: Enforcement of Legal Rights between Student and University. Australia and New Zealand Journal of Law and Education, 4(2): 18-37. 
Board of Examiners for re-marking. The Board marked it at zero and confirmed that they treated this as a failure and not a matter of plagiarism. Clark was allowed to resit her final and obtained an award of a third class degree which the student regulations provided was the usual award in such circumstances. She instituted a claim against the university in contract on the basis that the university was in breach of its contractual obligations by limiting the class of degree she could obtain on a second attempt. The university applied to have the proceedings struck out on the basis that the claim in contract was not justiciable. It argued that the relationship between a student and a university, as a public body, meant that a dispute was more properly covered in public law and to pursue a claim in contract was an abuse of process in that it circumvented the three month limitation period of judicial review. The Court of Appeal disagreed. It held that a student could have a claim in contract, even though the action could more appropriately be brought by judicial review proceedings. It said that the court would not strike out the claim merely because of the procedure which had been adopted. Importantly, in light of the Australian High Court decision in Tang, the judges in Clark accepted without question the availability of judicial review in respect of university decisions. Sedley LJ, delivering the opinion of the court saw the position as follows: ${ }^{59}$

\begin{abstract}
This is a matter of considerable importance in relation to litigation by dissatisfied students against universities. Grievances against universities are preferably resolved within the grievance procedure which universities have today ... If it is not possible to resolve the dispute, then the courts may have no alternative but to become involved. If they do so, the preferable procedure would usually be by way of judicial review. If, on the other hand, the proceedings are based on the contract between the student and the university then they do not have to be brought by way of judicial review. The courts today will be flexible in their approach.
\end{abstract}

Interestingly, Clark's case has an Australian equivalent, Ogawa $v$ The University of Melbourne, ${ }^{60}$ which raises some important legal issues about the nature of the relationship between a student and a public university. Although there have been numerous interlocutory 
applications, this matter is yet to be finally determined by a court. Unlike Tang, Ogawa is an international PhD student, who has not limited her claim to judicial review of the university's decisions regarding her candidature. Rather she alleges breach of contract and misleading and deceptive conduct on the part of the university regarding the manner in which her studies would be supervised and resourced. Given that the High Court in Tang decided that the university's decision was not subject to judicial review, the Ogawa litigation raises the possibility that a student in Australia may nonetheless have an alternative legal basis on which to proceed against a university in similar circumstances.

It is curious that in the Tang litigation it was accepted as common ground that the enrolment of the $\mathrm{PhD}$ student concerned did not give rise to a contractual relationship. In Lambv Massey University ${ }^{61}$ Wild $\mathrm{J}$ of the New Zealand High Court accepted the potential for a breach of contract action in such circumstances. However, he found that in that case the student's action failed on the facts. It is notable also that in the United States the courts have upheld the right to damages for breach of contract in an action by a doctoral student against the University of Southern Mississippi. In The University of Southern Mississippi $v$ Williams $^{62}$ the Supreme Court of Mississippi awarded damages for emotional stress and anguish following its finding that the university had failed to act in good faith and to deal fairly with the student. This case highlights a problem faced by a student pursuing an action for breach of contract. This is in relation to remedy.

\section{Does the student 'win the battle but lose the war'? Is there an appropriate remedy for breach of contract?}

\begin{tabular}{ll}
\hline 61 & n 16 \\
62 & 2004 WL 2536807 (Miss.2004).
\end{tabular}


A student who has been excluded from a course is most likely to want to be reinstated. This is particularly clear in the cases above. For these students the stakes were sufficiently high to expend the money, time and emotional expense in litigation. For Tang and Persaud the most important thing was to be able to continue their research and eventually to be awarded a PhD. This outcome is most likely to be achieved in an order of mandamus or certiorari following judicial review. If an action in contract is available, what would be the remedy sought? It is well established that the remedy of specific performance is not available when the contractual obligations are of an ongoing nature. Whether a court may grant an injunction to restrain the university from the breach or to require a remedial action is yet to be tested.

Would money suffice, and on what basis may damages be awarded? The potential for 'disappointment' damages was raised by the judge in the UK case, Buckingham and another $v$ Rycotewood College. ${ }^{63}$ This was an action by students at an Oxfordshire FE College for breach of a contract to educate. They alleged that the course content which 'they legitimately expected to be substantial and good, was low and often poorly taught'. Following a finding that there had been a breach, the question then became: how were the students to be compensated? In such a situation, similar to the Victoria University case above, there are some losses which are quantifiable, such as course costs, loss of income and the like. However, and this may be particularly so in the university cases, damages for anxiety and distress, and disappointment damages, are likely to be claimed. The general rule in contract is that damages relate to losses flowing from the breach and not to the circumstances surrounding the breach. They will not therefore usually be awarded for the mental suffering

63 Oxford County Court, 26 $^{\text {th }}$ March 2002, OX004741/OX 004342, His Honour Judge Charles Harris Q.C. 
of the innocent party so caused. ${ }^{64}$ The noted exception is where the object of the contract is to provide pleasure or that very state of mind which has been damaged. ${ }^{65}$ A 'breach of contract to educate' situation, said the judge in Rycotewood, may provide another exception. It is a short stretch to suggest that a further exception may be in the case of an adverse academic decision where breach of contract on the part of the university is proven. Certainly in such a situation it is highly probable that a student may claim damages for the anxiety and distress caused by the wrongful actions of the university. ${ }^{66}$ Likely too is a claim for damages for the disappointment caused by having been cut off from progression in a chosen career. Only time, as they say, will tell.

\section{An easier path for aggrieved students? Hope from the UK ...}

On 1 July 2004 the Higher Education Act 2004 (UK) came into force. This Act abolished the role of the visitor (in those universities in which it still existed) and established the Office of the Independent Adjudicator for Higher Education (OIA). The aim of the office is to provide an external and independent body to resolve student complaints. This body is set up in recognition of the imbalance which exists in the university/student relationship in terms of resources for litigation, and the difficulties faced by aggrieved students when they are unable to achieve satisfaction through the internal university procedures. Its aim is not to replace recourse to those internal procedures. Students must those procedures first before the matter will be taken up by the OIA. The OIA opened for business in March 2004 and 100 higher education institutions in England and Wales have voluntarily joined the scheme. It will be

See Palfreyman, D. (2003) Phelps ... Clark ... and now Rycotewood? Disappointment damages for breach of contract to educate Education and the Law, 15(4): 237-247. Palfreyman quotes the words of

$65 \quad$ Lord Bingham to this effect in Wade v Monroe [1991] 4 All ER 937.

$65 \quad$ As, for example, in Jarvis $v$ Swan Tours [1973] 1 All ER 71 (CA).

$66 \quad$ See The University of Southern Mississippi $v$ Williams n 61. 
interesting to watch its progress with the aim of its providing a template for similar systems in Australia and New Zealand.

\section{Conclusion - Where to academic immunity?}

The courts have been progressively defining the parameters within which they will subject university decisions to their scrutiny. It is clear now is that there are no hard and fast rules of demarcation and that the courts will be prepared to consider a student's challenge not within categories but within the facts and circumstances of every case. Whether it is a decision of pure academic judgment or one of academic discipline the common denominator which dictates the extent to which the courts will intervene is fairness and adherence to process. Thus the most important factor a student must demonstrate is not that the decision was flawed, but that the process by which it was made was flawed. ${ }^{67}$ In making the decision the university body concerned must have observed natural justice in that it must not only have complied with the policies and procedures of the university but also it must not have allowed extraneous elements to bring influence to bear. It seems that this would be the case whether the student chooses to apply for judicial review of the decision or whether he or she opts for an action in breach of contract or both.

In the scheme of things however, the number of cases reaching the courts is small. Anecdotal evidence suggests substantially more aggrieved students are deterred by the obstacles from pursuing their cause.

67 Davies, M. (2004) Challenges to 'academic immunity' - the beginning of a new era?

Education and the Law, 16(2-3); 75-96, at 1-2. 
It is regrettable that the majority in the High Court of Australia in Tang approached the matter solely as one of interpretation of the judicial review legislation and missed the real point. Elsewhere the focus is on the wider question: is there a weakening in the traditional reluctance of the courts to look behind decisions of academic judgement? Should this be so? There are many who feel the answer should be yes. ${ }^{68}$ The underlying questions are: why, unlike other professional groups, have academics remained largely immune from judicial interference and why have universities, unlike other publicly funded statutory institutions, remained relatively free from judicial review? Society’s trend towards greater transparency and accountability, together with the increasing commodification of education, means that these questions will not go away.

\section{Acknowledgment}

This article is based on a paper given at the $51^{\text {st }}$ Education Law Association Annual Conference at Memphis, Tennessee, USA, November 2005

$68 \quad \mathrm{n} 65$. 


\section{REFERENCES}

ASTOR, H. (2005) Improving Dispute Resolution in Australian Universities: Options for the Future, Journal of Higher Education Policy and Management, 27(1), pp.49-65.

BIRTWISTLE, T. (1998) Student Academic Appeals: a holistic assessment, Education and the Law,10(1), pp.41-54.

DAVIES, M. (2004) Challenges to 'academic immunity' - the beginning of a new era? Education and the Law, 16(2-3), pp.75-96.

DAVIES, M.R. (1996) Universities, Academics and Professional Negligence, Professional Negligence, 12, pp.102-116.

DAVIS, M. (2001) Students, Academic Institutions and Contracts - a ticking time bomb? Education and the Law, 13 (1), pp.9-28.

FARRINGDON, D.J. (1994) The Law of Higher Education (London, Butterworths).

FORD, D.L. \& STROPE, J.L. JR. (1996) Judicial Responses to Adverse Academic Decisions Affecting Postsecondary Institution Students Since "Horowitz" and "Ewing", Education Law Report, 110, pp.517-531.

HOYE, W.P \& PALFREYMAN, D. (2004) Plato v Socrates: the devolving relation between higher education institutions and their students, Education and the Law, 16(2-3), pp.97-112.

HYAMS, O. (1998) The Law of Education (London, Butterworths).

ILLING, D. (2005) Court Backs Griffith on Misconduct, The Australian, 9 March.

KAYE, T. (1999) Academic Judgement, the University Visitor and the Human Rights Act 1998, Education and the Law, 11(3), pp.165-186.

KOS, J.S. (2000) View from the Bottom of the Cliff: Enforcement of Legal Rights between Student and University, Australia and New Zealand Journal of Law and Education, 4(2), pp.18-37.

LIVINGSTONE, T. (2005) Uni Wins Student Dismissal Case, The Courier-Mail, 4 March.

MIDDLEMISS, S. (2000) Legal Liability of Universities for Students, Education and the Law, 12(2), pp.69-85.

MOODIE, G. (2005) Little Room for Review, The Australian, 9 March.

PALFREYMAN, D. (1999) The HEI-Student Legal Relationship, with special reference to the USA experience, Education and the Law, 11 (1), pp. 5-23.

PALFREYMAN, D. (2003) Phelps ...Clark ...and now Rycotewood? Disappointment damages for breach of the contract to educate, Education and the Law, 15(4), pp. 237-247. 
REDDY, M. (2004) The Office of the Independent Adjudicator for Higher Education: Preparing for the Statutory Scheme, Education Law Journal, pp. 1-5.

ROCHFORD, F. (1998) The Relationship Between the Student and the University, Australia and New Zealand Journal of Law and Education, 3(1), pp. 28-48.

ROCHFORD, F. (2005) Claims against a university: the role of administrative review in Australia and the United Kingdom, Education and the Law, 17(1-2), pp. 23-41.

SCHWEITZER, T.A. (1992) “Academic Challenge” Cases: Should Judicial Review Extend to Academic Evaluations of Students? The American University Law Review, 41, pp. 267-367.

STUHMCKE, A. (2001) Grievance Handling in Australian Universities: The case of the University Ombudsman and the Dean of Students, Journal of Higher Education Policy and Management, 23(2), pp.181-189.

VARNHAM, S. (1998) Liability in Higher Education in New Zealand: Cases for Courses? Australia and New Zealand Journal of Law and Education, 3(1), pp.2-18.

VARNHAM, S. (2001) Decisions of Academic Judgement and Discipline in New Zealand Tertiary Institutes: Do Cheats Prosper? Education and the Law, 13(4), pp.389-401.

VARNHAM, S (2002) Copping Out or Copying? Do Cheats Prosper? An Exploration of the Legal Issues Relating to Students Challenging Academic Decisions, Australia and New Zealand Journal of Law and Education, 7(1), pp.21-37. 